\title{
NOTES.
}

THE ORIGIN OF MONOCOTYLEDONS. - In the genus $\boldsymbol{P}_{\text {eperomia, a perfectly }}$ typical and normally dicotyledonous genus, a small group of geophilous individuals has been observed which are peculiar in showing a pseudo-monocotyledonous mode of germination. In this group the embryo is, as I think, without doubt dicotyledonous, but, owing to the assumption of different functions by the two cotyledons, a striking analogy to a monocotyledonous type of embryo has been produced.

In these Peperomias, as a reference to the published figures ${ }^{1}$ will show, one of the cotyledons remains within the seed and is entirely a suctorial organ, though it retains, to a certain extent, its dorsiventral structure and possesses rudimentary or rather degenerate stomata. The other cotyledon, however, leaves the seed, a permanent space being left in the seed by its withdrawal, and becomes an assimilating organ and thus assumes the appearance of the characteristic 'first-leaf' of Monocotyledons.

From a careful study of the germination of these geophilous forms, it has been suggested that the possible cotyledonary nature of the 'first-leaf' of Monocotyledons is worthy of some consideration.

In the Bull. Soc. Bot. Fr., sér. iv, vol. viii, I 908 , p. I65, MM. Buchet and Gatin describe and figure an interesting case of abnormal germination in Arisarum vulgare, Targ.-Tozz. The cotyledon, normally a suctorial organ embedded in the endosperm, appears to have aborted, or perhaps to have been torn off, at an early stage in its development, since traces of torn tissue, which may be interpreted as the remains of the cotyledon sheath, were found at the place where this organ should have occurred. In the absence of the cotyledon the 'first-leaf' had performed the functions of an absorbent organ, for the lamina was found enfolded in the seed and was somewhat thicker than that of the normal 'first-leaf', in consequence, apparently, of its altered

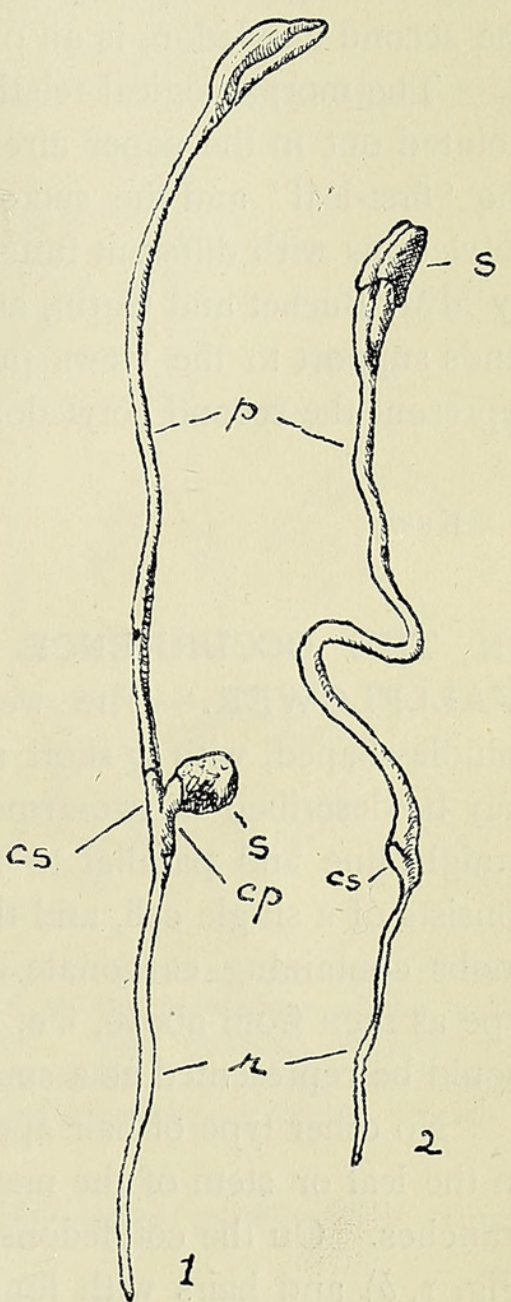

FIG. I. Normal seedling of Arisarum vulgare Targ.-Tozz.

FIG. 2. Abnormal seedling (nat. size): $s$. seed; $p$. petiole of the 'first leaf'; $c p$. petiole of the absorbent cotyledon; cs. cotyledonary sheath, represented by a small torn fragment in the abnormal seedling; $r$. radicle. (Copied from Bull. Soc. Bot. Fr., sér. iv, vol. viii, p. I66.) functions. The petiole had developed in the usual way, and the seed, with the ${ }^{1}$ Hill, A. W., in Ann. Bot., vol. xx, I906, Pl. XXIX and XXX and vol. xxi, Pl. XV. 
included lamina was carried into the air. The 'first-leaf' thus performed the functions of a cotyledon.

This may be considered to be the converse of the state of affairs met with in the geophilous Peperomias.

On the other hand, although without doubt there is an inversion in fact, this case of abnormal germination in Arisarum appears to lend support to the argument put forward in connexion with the germination of the Peperomias, since the 'first-leaf' is shown to be physiologically capable of performing cotyledonary functions. Whether or not it is legitimate to argue that in an abnormal case of this kind the 'first-leaf' is really showing a recapitulation of lost functions, and that it is in fact also morphologically the second cotyledon, is an open question.

The morphological relations of the cotyledon and 'first-leaf' in the Araceae were pointed out in the paper already referred to, ${ }^{1}$ and it does not seem improbable that the 'first-leaf' and the suctorial cotyledon really stand to one another as a pair of cotyledons with different functions. From this point of view the example described by MM. Buchet and Gatin, as far as it may be held to be of value in this connexion, lends support to the views put forward that the 'first-leaf' of Monocotyledons may represent the second cotyledon of the monocotyledonous embryo.

A. W. HILL.

KEw.

\section{ON THE OCCURRENCE OF DIFFERENT TYPES OF HAIR IN THE}

WALLFLOWER.-The well-known hairs on the leaves of the wallflower are spindle-shaped, with a short stalk at the middle attaching them to the leaf. They may be described as two-armed (malpighian) hairs having the two arms in the same straight line and parallel to the surface of the leaf. ${ }^{2}$ Each hair, including its stalk, consists of a single cell, and the surface of the spindle-shaped portion is studded with knobs containing carbonate of lime. Fig. I, $a$ shows the outline of a hair of this type as seen from above, i. e. in a surface-view of the leaf. In a lower focus the stalk would be represented as a small circle in the middle of the hair.

No other type of hair appears to have been recorded in the wallflower, or to occur on the leaf or stem of the mature plant, except on the lower leaves of some lateral branches. On the cotyledons, however, other forms are found, viz. three-armed hairs (Fig. I, $b$ ) and hairs with four (Fig. I, $c, d$ ), five (Fig. I, $e$ ) and, rarely, six arms. The two-armed type of hair, characteristic of the mature plant, occurs also on the cotyledons, but is usually far outnumbered by hairs with three or more arms.

On the upper side of the cotyledons the hairs may be many or few, but the proportional number of malpighian hairs (Fig. I, $a$ ) is nearly always small. Three-armed hairs appear to be the commonest, but on some cotyledons hairs with four or five arms predominate. On the lower side of the cotyledons the hairs are usually few, and often mostly of the two-armed type, but hairs with three or four arms also occur.

1 Hill, A. W. in Ann. Bot. xx, pp. 41 $7-422$.

${ }^{2}$ Some of the hairs have their arms bent slightly (or, rarely, sharply) upwards, away from the surface of the leaf. 


\section{$2 \mathrm{BHL}$ Biodiversity Heritage Library}

Hill, A. W. 1908. "The origin of monocotyledons." Annals of botany 22, 713-714. https://doi.org/10.1093/oxfordjournals.aob.a089196.

View This Item Online: https://www.biodiversitylibrary.org/item/232525

DOI: https://doi.org/10.1093/oxfordjournals.aob.a089196

Permalink: https://www.biodiversitylibrary.org/partpdf/318932

\section{Holding Institution}

Smithsonian Libraries

\section{Sponsored by}

Biodiversity Heritage Library

\section{Copyright \& Reuse}

Copyright Status: Not in copyright. The BHL knows of no copyright restrictions on this item.

This document was created from content at the Biodiversity Heritage Library, the world's largest open access digital library for biodiversity literature and archives. Visit BHL at https://www.biodiversitylibrary.org. 